6

\title{
PRESERVATION OF PANCASILA CULTURAL VALUES BY MILLENNIALS IN THE DEVELOPMENT OF TRENDS IN GLOBALIZATION ERA
}

\author{
Renata Noorawhita1, Moses Glorino Rumambo Pandin \\ Received: 18 Juni 2021; Accepted: 18 Agustus 2021; Published: 28 September 2021
}

Ed. 2021; 5 (1): 42 - 49

\begin{abstract}
Abstrak
Semakin kuatnya arus globalisasi saat ini membuat terciptanya banyak trend di kalangan generasi millennial. Kebanyakan trend yang berkembang saat ini adalah trend dengan "ideologi negara barat". Hal ini menunjukkan nilai budaya ideologi Pancasila mulai terkikis secara perlahan. Berdasarkan permasalahan tersebut, peneliti merumuskan suatu pertanyaan: Bagaimana peran generasi millennial saat ini melestarikan nilai budaya Pancasila? Purpose: Tujuan dari penelitian ini yaitu untuk mengetahui dampak trend yang ada di kalangan generasi millennial terhadap nilai budaya, mengetahui cara yang dapat dilakukan generasi millennial dalam melestarikan nilai-nilai budaya Pancasila. Method: metode yang digunakan dalam penelitian ini adalah literatur review, pencarian jurnal dilakukan melalui google. Wawancara tak langsung dengan generasi Millennial dan Observasi konten di Media Sosial. Results: Hasil dari penelitian ini menunjukkan pengaruh trend di generasi millennial pada nilai-nilai budaya Pancasila dan sejauh mana nilai budaya Pancasila dilestarikan oleh generasi millennial saat ini. Kesimpulan: Kesimpulan dari studi ini membahas aksi dari generasi milenial yang melestarikan nilai-nilai budaya Pancasila di tengah perkembangan tren dengan cara mereka sendiri.
\end{abstract}

Kata Kunci: Milenial, Globalisasi, Pancasila, Generasi Muda, Perkembangan Tren, Nilai-nilai Budaya Pancasila.

\section{INTRODUCTION}

At this time, the development trend is very diverse in the younger generation. This is due to the strong current of globalization that occurs in a country. Actually, globalization itself has been known to humans since the 15th century, followed by the phenomenon of trade between countries. Each country exerts its influence on the country that is the destination of its trade with the aim of expanding the reach of its country and competing to introduce their culture to other countries. This is what gives rise to a new trend phenomenon among the younger generation. Globalization that causes the emergence of a trend is actually not a bad thing for life, considering the initial goals of globalization. Globalization itself can be used as a forum for cultural exploration to get to know each other's cultures in the world, The bad impact of globalization arises because of the response of the people in a country. The community is considered less appreciative and more proud of the culture that has just entered their country. The community considers that their culture is too ancient to continue to be developed and prefers new cultures from foreign countries because they are considered modern and cool. This is what happened to 
the millennial generation in Indonesia. Many of them have been exposed to this current of globalization, thus making them accept foreign cultures easily and replace local cultures so quickly. Placing foreign culture into the value of life can be a serious threat to the preservation of a country's local cultural values. Cultural values themselves are a form of a country's identity, if the country loses their local cultural values then the country has directly lost their identity. So that this does not happen, the millennial generation needs awareness pressure to move directly. Take real action to continue to implement the local cultural values contained in Pancasila in the joints of community life at large. Therefore, we need to know what is the role of the current millennial generation in preserving the cultural values of Pancasila? This study explores the role of the millennial generation in preserving the cultural values of Pancasila in the development of trends in the era of globalization.

\section{METHOD}

This case study uses the literature review method by using research articles based on the theory, ideas, and understanding of the researcher. In addition, the researcher uses an indirect interview method with the millennial generation through the Line and messenger message exchange applications as well as observational analysis of Instagram, Youtube, and Tiktok social media. Literature review is a method used by researchers in case study tests based on journals or articles that are relevant to the study theme raised by the researcher. Data collection was carried out using Google and took 5 articles as the main reference for collecting information for this case study. The data analysis used is an analysis by taking the topic points of discussion of each article used as in the previous description.

Table 1. Literature Search Keywords

\begin{tabular}{|l|l|l|}
\hline Millennials & Globalization & Pancasila \\
\hline $\begin{array}{l}\text { Young } \\
\text { generation }\end{array}$ & $\begin{array}{l}\text { Trend } \\
\text { development }\end{array}$ & $\begin{array}{l}\text { Cultural } \\
\text { values of } \\
\text { Pancasila }\end{array}$ \\
\hline
\end{tabular}

Indirect interviews are questions and answers with today's millennials through the messaging application Line (an application originating from Japan) and Messenger (a messaging application supported by Facebook). In this indirect interview, researchers took 6 millennial generation respondents who are peers and actively use social media and know the development of ongoing trends. Meanwhile, social media observation analysis is a technique of taking data through direct observation of content on 3 social media, namely Instagram, Youtube, and Tiktok. These 3 social media are believed to be the most widely used social media by the millennial generation today. The results of this social media observation analysis will be written in the form of data in a table. In writing the article, inclusion criteria were used in the form of articles published in the range of 2019 to 2021, research with the theme of Pancasila cultural values, millennials, and globalization. In addition, there are also indirect interviews with the Line and Messenger messaging applications, and analysis of observations of social media content on Instagram, Youtube, and Tiktok.

\section{RESULTS}

Table 2. Types of trends that have developed over the last 3 years.

\begin{tabular}{|l|l|l|l|}
\hline Year & $\begin{array}{l}\text { Types of } \\
\text { emerging } \\
\text { trends }\end{array}$ & $\begin{array}{l}\text { A culture that is } \\
\text { more reflected } \\
\text { among the } \\
\text { millennial } \\
\text { generation }\end{array}$ & $\begin{array}{l}\text { The visible form of } \\
\text { the trend }\end{array}$ \\
\hline 2019 & $\begin{array}{l}\text { Social Media } \\
\text { Instagram \& } \\
\text { Youtube) }\end{array}$ & $\begin{array}{l}\text { The Western } \\
\text { culture }\end{array}$ & Lifestyle \\
\hline 2020 & $\begin{array}{l}\text { Fashion \& K- } \\
\text { pop }\end{array}$ & $\begin{array}{l}\text { Western culture- } \\
\text { Korean culture }\end{array}$ & Lifestyle \& shows \\
\hline 2021 & Tiktok & $\begin{array}{l}\text { Western culture- } \\
\text { Korean culture }\end{array}$ & Lifestyle \& shows \\
\hline
\end{tabular}

Based on the analysis in table 3, it is found that every year there must be a new trend among the younger generation, as in the last 3 years, namely between 2019-2021, data obtained from articles and surveys regarding what types of trends are most followed by the younger generation, namely the millennial generation. These trends include, in 2019, the type of trend most followed by the millennial 
generation, namely social media trends in the form of Instagram and YouTube by showing their lifestyle more. In 2020, the types of trends that are widely followed are fashion trends and K-pop (a genre of music originating from South Korea) by showing more lifestyle \& shows. And in 2021 or recently it was found that many millennials really like and follow the trend of Tiktok (a social media application originating from China) which also shows more lifestyle and shows. This data was obtained based on a survey conducted by researchers with indirect interviews using the Messenger and Line applications (an application as an exchange of messages originating from Japan) to fellow millennials of the same generation. In the data exposed in table 3, of the trends that have emerged over the last 3 years, all of them carry more foreign cultures, namely western and Korean culture. There is no single trend that is more indicative of Indonesian culture like the cultural values of Pancasila. Directly, these trends have changed the lifestyle of the millennial generation to adopt more foreign cultures and will slowly leave the lifestyle of the Indonesian nation's culture. Based on this data, it cannot be covered up that new trends will emerge as the years go by because if you look at the trend of the younger generation who are more interested in foreign cultures, they are more attractive and never out of time. This shows that slowly Indonesian cultural values will be abandoned by the younger generation and may become extinct one day. it cannot be covered if new trends will emerge as the years go by because if you look at the trend of the younger generation who are more uplifting of foreign cultures, they are more desirable and never out of time. This shows that slowly Indonesian cultural values will be abandoned by the younger generation and may become extinct one day. it cannot be covered if new trends will emerge as the years go by because if you look at the trend of the younger generation who are more uplifting of foreign cultures, they are more desirable and never out of time. This shows that slowly Indonesian cultural values will be abandoned by the younger generation and may become extinct one day.

Table 3. Comparison of the preservation of Pancasila cultural values with the development of trend followers.

\begin{tabular}{|l|l|l|}
\hline Year & $\begin{array}{l}\text { Presentation } \\
\text { of people who } \\
\text { preserve Pancasila } \\
\text { culture }\end{array}$ & $\begin{array}{l}\text { Presentation } \\
\text { of trend } \\
\text { followers }\end{array}$ \\
\hline 2019 & $30 \%-40 \%$ & $60 \%-70 \%$ \\
2020 & $20 \%-30 \%$ & $70 \%-80 \%$ \\
2021 & $20 \%-10 \%$ & $80 \%-90 \%$ \\
\hline
\end{tabular}

In addition, it can also be seen from the data analysis table 4 which shows the comparison of the percentage of people who still preserve the culture of the Indonesian nation with the percentage of the millennial generation who follow the trend. In the last 3 years, namely between 2019-2021, it was found that the percentage of people who preserve the culture of the Indonesian nation is decreasing from year to year. Meanwhile, the percentage of the millennial generation who follow the trend is increasing rapidly from year to year. The comparison of the two numbers is also very significant where the percentage of the millennial generation who follows the trend is more than those who still preserve the cultural values of the Indonesian nation. A sizeable comparison exists in 2021 at this time. This data shows the fact that many millennials are more interested in following emerging trends than continuing to preserve the cultural values of the Indonesian nation. There is data taken based on indirect interviews through the Line message exchange media, a millennial generation said that the current number of young people who really preserve the nation's cultural values and do not follow the trend is certainly not there. Meanwhile, a young generation who continues to preserve the nation's culture despite following the trend is very few in number and if there is they must be under the auspices of 
an institution for the empowerment and preservation of the nation's culture. This is quite disturbing for the sustainability of the nation's cultural values in people's lives.

\section{DISCUSSION}

\section{Impact of globalization}

Globalization has brought many changes to the lives of the Indonesian millennial generation. One of the most troubling impacts is the emergence of trends among the younger generation. The emergence of a trend itself is not a bad thing if the millennial generation can filter well and not be too excessive to apply life with the cultural values that appear in the emerging trend. According to Dr. Nayef RF Al-Rodhan, globalization includes the causes, cases, frequency of national and transcultural integration of humans and non-humans. The development of trends due to globalization itself has a significant impact on the sustainability of the cultural values of the Indonesian nation in accordance with the state ideology, namely Pancasila.

Table 4. The perceived impact that will emerge from the trend development.

\section{General impact:}

1. The emergence of a new culture in a nation that allows the younger generation to leave the culture of their own nation.

2. In terms of people's lives and mindsets, they will change following the new culture that emerges from a trend.

3. The cultural values of the original nation which become the national identity will lose competitiveness with the new culture that is in a trend because of the response of the millennial generation who view that the culture that is in the trend is a modern thing.

\section{Serious impact:}

1. There is no longer any implementation of cultural values based on Pancasila as the ideology of the Indonesian state if the millennial generation does not want to preserve them.

2. The erosion of the millennial generation's sense of nationalism towards their nation and country.

3. The loss of national culture is simply caused by the millennial generation's excessive pride in foreign cultures.

From table 5 we can get information that the ongoing trend developments among the millennial generation can cause 2 categories of impacts, including general impacts and serious impacts. If we look at the general impact that arises from the development of trends, it can threaten the continuity of the cultural values of the Indonesian nation. Meanwhile, a serious impact can result in the millennial generation losing their identity as the Indonesian Nation. Therefore, the preservation of cultural values based on the values contained in Pancasila must be carried out by the current millennial generation.

\section{Cultural values in Pancasila}

According to Kaelan, Pancasila was appointed based on the values of customs, cultural values of the Indonesian nation that exist in the life of the community and aims to unite the entire community into one Indonesian national identity (KAELAN, 2004; in a journal published by eprints.ums)

Table 5. Cultural values contained in Pancasila.

\begin{tabular}{|l|l|}
\hline $\begin{array}{l}\text { Cultural } \\
\text { Values contained } \\
\text { in Pancasila }\end{array}$ & Mean \\
\hline Divine Value & $\begin{array}{l}\text { God Almighty teaches } \\
\text { people to embrace } \\
\text { religion according } \\
\text { to their beliefs and } \\
\text { respect each other } \\
\text { with fellow religious }\end{array}$ \\
\hline
\end{tabular}




\begin{tabular}{|l|l|}
\hline Unity Value & $\begin{array}{l}\text { Unity of Indonesia } \\
\text { teaches the public to } \\
\text { maintain the unity of } \\
\text { the Indonesian state } \\
\text { and maintain broth- } \\
\text { erhood with fellow } \\
\text { Indonesians in order } \\
\text { to maintain the identity } \\
\text { of the people as the } \\
\text { Indonesian nation. }\end{array}$ \\
\hline Human Values & $\begin{array}{l}\text { A just and civilized hu- } \\
\text { manity teaches people } \\
\text { in speaking behavior so } \\
\text { that they respect each } \\
\text { other, help, love, and } \\
\text { care for their fellow } \\
\text { Indonesians. }\end{array}$ \\
\hline Community & $\begin{array}{l}\text { Democracy led by } \\
\text { wisdom in deliberation } \\
\text { and representation } \\
\text { teaches the public that } \\
\text { the Indonesian nation is } \\
\text { a democratic nation, in } \\
\text { every decision making } \\
\text { based on the principle } \\
\text { of deliberation for } \\
\text { consensus. }\end{array}$ \\
\hline Justice & $\begin{array}{l}\text { Social justice for all } \\
\text { Indonesian people } \\
\text { teaches the community } \\
\text { to respect the rights of } \\
\text { others because every } \\
\text { human being has differ- } \\
\text { ent rights and has been } \\
\text { carried since they were } \\
\text { born. }\end{array}$ \\
\hline
\end{tabular}

There are 5 community cultural values listed in the Pancasila ideology. These 5 values have long been the identity of the Indonesian nation and have been implemented since Indonesia's independence, namely 1945. From the table, many values have now been distorted by the millen- nial generation due to globalization and trend developments that occur every year.

Table 6 Pancasila cultural values perverted by the millennial generation.

\begin{tabular}{|c|c|}
\hline $\begin{array}{l}\text { Cultural values } \\
\text { in Pancasila }\end{array}$ & $\begin{array}{l}\text { Forms of abuse by the } \\
\text { millennial generation. }\end{array}$ \\
\hline Divine value & $\begin{array}{l}\text { There is terrorism in the } \\
\text { name of religion and } \\
\text { attacks places of worship } \\
\text { for other religious people } \\
\text { and insults other religions. }\end{array}$ \\
\hline Human values & $\begin{array}{l}\text { Insinuating each other } \\
\text { on social media, which } \\
\text { is mostly done by public } \\
\text { figures, is considered to } \\
\text { have no mutual respect, } \\
\text { love and affection among } \\
\text { fellow Indonesians. }\end{array}$ \\
\hline Unity valuea & $\begin{array}{l}\text { Ethnic discrimination that } \\
\text { discriminates against a } \\
\text { person's skin color and is } \\
\text { widely displayed in beauty } \\
\text { product advertisements } \\
\text { on tv. }\end{array}$ \\
\hline Social value & $\begin{array}{l}\text { Acting vigilantly without } \\
\text { deliberation and good } \\
\text { discussion first. }\end{array}$ \\
\hline $\begin{array}{l}\text { Value of } \\
\text { social justice }\end{array}$ & $\begin{array}{l}\text { Stepping on the rights } \\
\text { of others such as not } \\
\text { respecting other people's } \\
\text { life time and acting as } \\
\text { they please others, this is } \\
\text { often found in schools } \\
\text { with bullying. }\end{array}$ \\
\hline
\end{tabular}

There have been many forms of misappropriation of Pancasila cultural values by the younger generation today. If left unchecked, this will threaten and get rid of the cultural values contained in Pancasila. In addition, 
there are also behaviors that deviate from the cultural values of Pancasila and are often found in the current generation, namely western culture and Korean culture. These two cultures can replace the cultural values of Pancasila if there are no implementation and preservation actions by the current millennial generation.

\section{Preservation of Pancasila cultural values by today's millennial generation}

Measures to prevent the decline of cultural values contained in Pancasila need to be implemented from now on, both by the millennial generation and other Indonesian people. This precautionary measure can anticipate that every time there is a new trend development among the younger generation, the trend will not eliminate the original culture of the Indonesian nation. Millennial generation and other Indonesian people can take several preventive actions, such as:

1. Cultivating a sense of nationalism to the younger generation so that they are not too excessive in responding to a trend and can have the desire to continue to preserve the original cultural values of the Indonesian people even though they follow a trend.

2. Instilling and practicing the values of Pancasila in the lives of today's young generation, learning about the importance of Pancasila values in the elements of life needs to be re-emphasized in the younger generation.

3. Instilling and implementing good and true religious teachings because the values of religious teachings teach their people to maintain peace and not create hostility. In addition, the existence of prohibition laws in religious teachings can keep the younger generation from acting.

4. Be more selective about the influence of globalization, especially a trend. The younger generation is expected to be able to distinguish which culture is from a trend that we can still take and apply in Indonesia because it has the same elements as the cultural values in Pancasila.

Based on the results of the author's analysis of observations in today's social media such as Instagram, Youtube and Tiktok, it was found that there is still content created by the millennial generation to support the culture of the Indonesian nation. The following are data obtained from observations on social media.

Table 7. content analysis in accordance with cultural values in Pancasila

\begin{tabular}{|l|l|}
\hline $\begin{array}{l}\text { Cultural values } \\
\text { in Pancasila }\end{array}$ & $\begin{array}{l}\text { Content found on so- } \\
\text { cial media (Instagram, } \\
\text { Youtube, and Tiktok) }\end{array}$ \\
Thine value & $\begin{array}{l}\text { There is content on } \\
\text { Youtube, Instagram and } \\
\text { Tiktok that seeks to in- } \\
\text { crease mutual respect and } \\
\text { respect between fellow } \\
\text { religious people by saying } \\
\text { that 'religion is also about } \\
\text { humanity'. }\end{array}$ \\
\hline Human values & $\begin{array}{l}\text { There is a lot of content } \\
\text { on Youtube, Instagram } \\
\text { and TikTok that raises } \\
\text { the theme of humanity, } \\
\text { such as social experiment } \\
\text { content which shows that } \\
\text { the millennial generation } \\
\text { now prioritizes human } \\
\text { values in their lives. }\end{array}$ \\
\hline Unity value & $\begin{array}{l}\text { A lot of content on You- } \\
\text { tube and Instagram that } \\
\text { opens the mindset of } \\
\text { outsiders such as content } \\
\text { that states that 'skin color } \\
\text { doesn't determine beauty' } \\
\text { or 'beauty doesn't have } \\
\text { to be white'. This will } \\
\text { open the mindset of the }\end{array}$ \\
\hline
\end{tabular}




\begin{tabular}{|l|l|}
\hline | & $\begin{array}{l}\text { younger generation to not } \\
\text { discriminate against skin } \\
\text { color. In addition, there is } \\
\text { a Youtube Rewind video } \\
\text { in } 2020 \text { which was made } \\
\text { with the theme "Unity to } \\
\text { become one identity of } \\
\text { the Indonesian nation is } \\
\text { something to be proud } \\
\text { of for the millennial } \\
\text { generation. }\end{array}$ \\
\hline Social value & $\begin{array}{l}\text { Youtube content such } \\
\text { as podcasts teaches the } \\
\text { younger generation to } \\
\text { deliberation and dis- } \\
\text { cussion in response to a } \\
\text { problem. }\end{array}$ \\
\hline Value of social & $\begin{array}{l}\text { The amount of content } \\
\text { that opposes and de- } \\
\text { scribes the bad effects } \\
\text { of bullying such as story } \\
\text { telling or short films by } \\
\text { the millennial gener- } \\
\text { ation teaches the next } \\
\text { generation to respect the } \\
\text { rights of others. }\end{array}$ \\
\hline
\end{tabular}

Based on the analysis of observing content on social media, it can be said that the current millennial generation still preserves the culture of the Indonesian nation even though it follows the development of trends in the current era of globalization. Several young generations are currently preserving cultural values by incorporating them into several trends. For example, in Tiktok there is a Buss it Indonesia trend, where the millennial generation makes a fashion transition by using batik as Indonesian culture rather than following western clothing culture that is not in accordance with the norms and culture of the Indonesian nation. Therefore, at present, the millennial generation is doing a lot of cultural preservation by utilizing technology and trends to further introduce the culture of the
Indonesian nation to other countries.

\section{CONCLUSION}

This era of globalization is indeed very disturbing with the development of a trend among the younger generation that favors western and Korean culture. The development of this trend has had an impact on the lives of the younger generation who are more adopting western culture and Korean culture. Data obtained from indirect interview surveys on the millennial generation and observations of social media content show that more young people follow trends and implement a culture that stands out from these trends in life than young people who truly preserve the nation's culture, even the percentage of people's values. preserving the nation's culture has been decreasing from year to year.

There are many forms of abuse of cultural values in accordance with Pancasila in people's lives. Unfortunately, all forms of abuse are shown in public media such as television, which has a fairly broad and comprehensive coverage. In addition, social media is the main key to the dissemination of forms of abuse of cultural values to the community. Public figures who are supposed to set a good example are actually doing a form of misappropriation of the cultural values of the people that exist in Pancasila. What causes many people to imitate the actions of these public figures, especially those of the millennial generation.

However, it was found in social media observations that there are still millennials who spread content to fight this form of abuse and still preserve the cultural values that exist in Pancasila. Even though they still follow the trends that are developing today, the millennial generation has their own way of responding to these trends. The millennial generation carries out cultural assimilation between cultural values and developing trends, they take advantage of existing trends to better introduce Indonesian culture. So, although only a few millennials continue to preserve Indone- 
sian culture, at least the cultural values of the Indonesian people do not fade and just disappear from Indonesian society.

\section{ACKNOWLEDGEMENT}

First, I Want to say thank you to God who has blessed and provided smoothness in the preparation of my study journal articles this time. The study journal article entitled "Preservation of Pancasila Cultural Values by the millennial generation in the development of trends in Globalization Era" is a journal article created to fulfill the final value of the Pancasila Course, Faculty of Psychology at Airlangga University Surabaya. In the preparation of this study journal article, many people have helped me in supporting the search for supporting data for this research. My friends who volunteered to be 6 millennial generation respondents and were willing to be interviewed trough messaging application media, namely Line and Massanger. I would to thank my friends who have been willing to share their ideas and thoughts in my data collection. Last but not least, I would like to highly appreciate my Pancasila subject lecturer, Dr. Moses Glorino Rumambo Pandin who has helped to tell me the website that supports the publication of my journal article this time. Also with him I get basic Materials in the preparation of my study journal articles.

\section{REFERENCES}

Mohd Azmi, M. Rafiuddin.

2019. Sosial Media dan Generasi Muda Menurut Islam. Religious Journal. 1(1): 89-93.

Wardana, Dodi Jayana; Handayani, Anita; Rahim, Andi Rahmad; Sukaris; Fauziyah, Nur.

2021. Sosialisasi Pentingnya Nilai-Nilai Pancasila. Journal of Community Service. 3(1): 775-777

Eprints.ums.ac.id. Bab I ACC.pdf. Accessed

2021. June 18, 2021, fromhttp:/ / eprints. ums.ac.id/66613/12/BAB $\% 201 \% 20$ ACC.pdf
SetYaWAn, AriF; WahyUdianto, Arif; UtOmo, Budi; Samosir, Enson E; Hamda, Noval; ANDARU, SANityoso.

2021. Lunturnya Nilai-Nilai Pancasila. Faculty of Social Sciences UNY:

Yogyakarta. Accessed on June 18, 2021, from http:/ /staffnew. uny.ac.id/upload/132093042/ Pen didikan/lunturnya-kulturpancaslasiap-upload.pdf

Permatasari, OS, Hanita, M.

2021. Perspektif Generasi Milenial terhadap Pancasila. Jurnal Ilmiah Hukum dan Dinamika Masyarakat. 19(1).

Gultom, Armyn.

2019. Implementasi Pancasila dalam Menjaga Eksistensi Bangsa. Kajian Ilmu Sosial. 30(1). 